\title{
Short-term dynamics of cladocerans in a eutrophic shallow lake during a shift in the phytoplankton dominance
}

\author{
Nelson Abrantes*, António Nogueira and Fernando Gonçalves \\ CESAM \& Department of Environment, University of Aveiro, 3810-193 Aveiro, Portugal
}

Received 10 July 2009; Accepted 4 September 2009

\begin{abstract}
The changes in the dynamics of cladocerans in Lake Vela (Portugal), as well as the morphologic and life history traits of the small-bodied cladoceran Ceriodaphnia pulchella, were studied intensively during one month characterized by deep and fast changes in the phytoplankton community: the beginning of the cyanobacteria dominance. Lake Vela, located in the Mediterranean region, is a polymictic shallow lake exhibiting characteristics typical of an advanced trophic status, namely the permanently turbid water, the reduction in biodiversity and the occurrence of cyanobacteria blooms. The density and composition of the cladocerans populations varied considerably during the short-term period analyzed. Coincident with the increase of cyanobacteria, the density of Daphnia longispina decreased drastically, associated with an increase of Bosmina longirostris and Chydorus sp. The constant density of C. pulchella, even during the cyanobacteria dominance, and the strong relationship found between weight and size, suggests that the low quality of phytoplanktonic food in Lake Vela did not play an important role in its fitness. Besides the small size of C. pulchella, this fact could be also related to its diversified diet. Nevertheless, a closer examination of the life history parameters of $C$. pulchella revealed a reduction in the fecundity, size at first reproduction, mean size of ovigerous females and maximum size of the population, which suggest an increase of the fish pressure after the decline of Daphnia. C. pulchella showed also a short-life cycle and a fast turnover of individuals, which constitutes also an advantage, allowing a fast adaptive response of the population.
\end{abstract}

Key words: Mediterranean shallow lakes / short-term dynamics / cladocerans / cyanobacteria / Ceriodaphnia pulchella

\section{Introduction}

Zooplankton holds a central position in most temperate lakes, reservoirs and ponds. In particular, cladocerans, which generally contribute largely to zooplankton biomass (Hessen et al., 2003), are a key element in the freshwater food webs. They control the algal growth by efficient grazing, and are important diet for zooplanktivorous fish (e.g., Christoffersen et al., 1993). Thus, cladocerans are an important link in the transmission of the energy from the primary producers to the top consumers.

Cladocerans are constantly exposed to a great variety of environmental factors, whose fluctuations constrain the size, reproduction and survival of populations. According to the conceptual model developed by the Plankton Ecology Group (PEG model), the most important environmental factors controlling zooplankton dynamics are water temperature, supply of edible phytoplankton and fish predation (Sommer et al., 1986). Water

\footnotetext{
*Corresponding author: njabrantes@ua.pt
}

temperature constrains the life history traits of zooplanktonic organisms by changing metabolic rate and activity level, with direct effects on growth and reproduction (Burns, 1969; Goss and Bunting, 1983; Orcutt and Porter, 1984). In freshwater ecosystems, cladocerans are faced with a great diversity of resources of different quality. Since their capacity of selection is limited, the quality and quantity of food are determinants in their life history traits (Lampert, 1978; Vanni and Lampert, 1992; MüllerNavarra and Lampert, 1996; Greenwood et al., 1999; Hulsmann, 2001; Becker and Boersma, 2003). Direct and indirect effects of fish are also key factors in the structuring of cladoceran communities. In addition to the large impact of size selective predation, zooplanktivorous fish also influence the morphology, life history traits and behaviour of zooplanktonic prey species through the release of infochemicals (Stibor, 1992; Gliwicz, 1994; Reede, 1995; Boersma et al., 1998).

Cladocerans are known to deal with environmental pressure through a variety of adaptive responses, including phenotypic plasticity (Lampert, 1993, 1994; Boersma et al., 

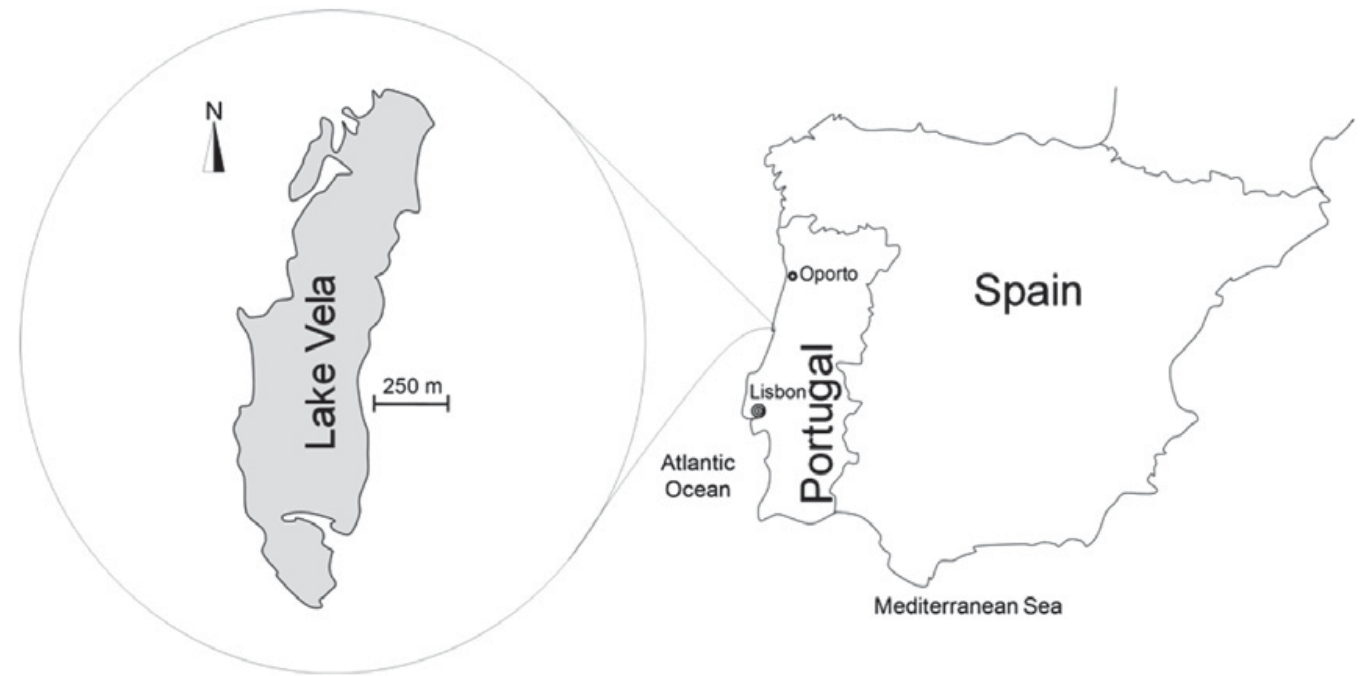

Fig. 1. Location of Lake Vela (Figueira da Foz, Portugal).

1998; Tollrian and Dodson, 1999). One of the best-studied examples of inducible defences are the responses exhibited by Daphnia to predation. Daphnids are able to adapt their life history performances (e.g., size and age at maturity), their morphology (e.g., neck spines) or their behaviour (e.g., dial vertical migration) (Hulsmann et al., 2004). Likewise, depending on the food quantity, Daphnia is also able to adjust their life history traits to optimally allocate the available resources. In low-food conditions, daphnids allocate more energy resources to self-maintenance in detriment to reproduction, while at high-food supply their investment in reproduction is favoured (Polishchuk and Vijverberg, 2005; Smolders et al., 2005). Lampert and Brendelberger (1996) also report the investment of Daphnia species in more efficient mechanisms of food collection as an adaptation to low-food concentrations (e.g., larger filter combs, mesh sizes, and appendage beat rates).

Shallow lakes in the Mediterranean region, and particularly in the Iberian Peninsula, constitute singular ecological niches and are important reservoirs of biodiversity (Castro and Goncalves, 2007). However, the vast majority of this type of ecosystem is long facing eutrophication, a process that is accelerated by anthropogenic activities. Lake Vela, located at the west coast of Portugal, is no exception. Massive cyanobacteria blooms (e.g., Aphanizomenon flos-aquae and Microcystis aeruginosa blooms) have become increasingly frequent and large fish kills have occurred in recent years in Lake Vela (Abrantes et al., 2006; de Figueiredo et al., 2006). Moreover, the native fish community has been completely replaced by alien fish (mainly pumpkinseed sunfish). Sampling programs recently performed have also shown that Daphniadominance periods were short and that small-bodied forms were usually dominant (Abrantes et al., 2006; Castro and Goncalves, 2007). Therefore, this lake is becoming a progressively more impoverished ecosystem, hence requiring a full understanding of its present status in order to implement restoration measures.
Although demographic studies with zooplanktonic species and general hypotheses and patterns of plankton succession are well described for temperate lakes (Sommer et al., 1986), only a few studies have appeared on shallow lakes with Mediterranean climate and extreme eutrophic conditions associated to cyanobacteria blooms. Moreover, the generality of the studies have focused on the role of Daphnia, and little attention has been paid to the role of small-bodied cladocerans in the food web (e.g., Balseiro et al., 1992; Vijverberg and Boersma, 1997; Greenwood et al., 1999; Viroux, 2002), which are generally more abundant than large-bodied species (i.e., Daphnia) in eutrophic lakes.

In this study, particularly focused on the small-bodied cladoceran Ceriodaphnia pulchella, we intend to provide additional information on the dynamics of cladocerans in lake Vela during a short-term period characterized by deep and fast changes in the plankton community: the beginning of the cyanobacteria dominance. Moreover, we aim also to gain better insight into adaptive responses of $C$. pulchella to deal with those new environmental conditions.

\section{Material and methods}

\section{Study site}

Lake Vela, located in the west coast of Portugal $\left(40^{\circ} 5^{\prime} \mathrm{N} 8^{\circ} 8^{\prime} \mathrm{W}, 45 \mathrm{~m}\right.$ a.s.l), is a temperate eutrophic shallow lake (mean depth $=0.9 \mathrm{~m}$; maximum depth $=2.4 \mathrm{~m}$ ) with 70 ha of surface area and a total volume of $70 \times 10^{4} \mathrm{~m}^{3}$ (Fig. 1). It is surrounded, on the east side, by agricultural lands and some human settlements and, on the west side, by a Pinus spp. forest. Due to the regular nutrient inputs, the lake is highly eutrophic (Abrantes et al., 2006). It is characterised by permanently turbid water, without a spring clear water phase, and algal blooms are frequently observed, namely in the warmer seasons. 
The phytoplankton is dominated by cyanobacteria, Bacillariophyceae (e.g., Cyclotella spp.) and Chlorophyta (de Figueiredo et al., 2006). Submerged macrophytes are scarce and the macrophyte community is dominated by Nymphaea alba (Castro and Goncalves, 2007). The crustacean zooplankton is dominated by small-bodied cladocerans, cyclopoid copepods and nauplii. The main planktivorous fish in Lake Vela are Lepomis gibbosus, Gambusia holbrooki and Micropterus salmoides, which are all species introduced in the last century (Castro and Goncalves, 2007).

\section{Sampling strategy and parameters analysed}

Sampling was carried out every other day near surface $(0.4 \mathrm{~m}$ in average) in the pelagic zone of the lake, during approximately one month (from March 31 to May 2 of 2001). Water temperature, conductivity, $\mathrm{pH}$ and dissolved oxygen were determined in situ using portable probes (WTW LF 330 conductivity meter, WTW 340-A pH meter and WTW OXI 320 oxygen meter). For cladoceran analysis, 20-L water samples (three replicates per sampling) were collected and concentrated by filtration through a $55-\mu m-m e s h$ screen. Each sample was immediately placed in 4\% sugar formalin for zooplankton preservation (Haney and Hall, 1973). In the laboratory, zooplankton samples were sorted and cladoceran taxa were identified and enumerated through a binocular stereoscope, using the keys of Scourfield and Harding (1966) and Amoros (1984a, 1984b). Chlorophyll $a$ was taken as a measure for total phytoplankton biomass, and was determined spectrophotometrically according to methodologies described by (A.P.H.A., 1995). Phytoplankton samples were collected in the beginning, in the middle and at the end of the study (March 31, April 14 and May 2, respectively). One-L samples were preserved in lugol $(1 \% \mathrm{v} / \mathrm{v})$ for later identification and enumeration. The identification of phytoplankton species was made by observation through a light microscope using different references for Cyanoprokaryota (Geitler, 1932; Komárek and Anagnostidis, 1999), Bacillariophyceae (Krammer and Lange-Bertalot, 1986-1991) and Chlorophyta (Chlorococcales) (Komárek and Fott, 1983). The enumeration was performed according to Lund et al. (1958) with at least 400 cells counted.

\section{C. pulchella population analysis}

For C. pulchella, in addition to the abundance data, the body-length was also measured (from the top of the head to the base of the tail spine), as well as the fecundity (number of eggs per adult). Demographic parameters were calculated following (Paloheimo, 1974). The instantaneous birth rate $(b)$ was determined according to equation (1):

$$
b=\ln \left(1+E_{0} / n_{0}\right) / D
$$

where $E_{0}$ is the number of eggs, $n_{0}$ the number of individuals and $D$ is the egg development time in days.
The egg development time was obtained from laboratory experiments (Abrantes and Goncalves, 2003). The presence of males, ephippia and cyclomorphosis, were recorded whenever they occurred. The size at first reproduction was estimated according to Lampert (1988). The rate of population increase $\left(r, \mathrm{day}^{-1}\right)$ was calculated from the equation (2):

$$
r=\left(\ln n_{t}-\ln n_{0}\right) / t
$$

where $n_{0}$ is the initial population size, $n_{t}$ is the final population size, and $t$ the time interval between two sampling dates (Wetzel, 1993). The death rate $(d)$ was determined by the equation (3):

$$
d=b-r \text {. }
$$

The biomass of approximately 400 specimens of $C$. pulchella was estimated and a length-dry weight regression analysis was performed according to Bird and Prairie (1985) (4):

$$
\mathrm{Ln} C=\ln a+b \ln L
$$

where $a$ and $b$ are fitted constants, $C$ is the weight $(\mu \mathrm{g})$ and $L$ the body length $(\mathrm{mm})$. Linear regression analyses were also used to determine the significance of the relationships between $C$. pulchella population parameters and biotic and abiotic variables.

Since cladocerans reproduce continuously, it is impossible to distinguish cohorts directly. Therefore, to analyse the cohorts' evolution along the study period, we performed a modal analysis on the females' body length frequencies, using the software ANAMOD (Nogueira, 1992).

\section{Results}

\section{Environmental parameters and cladoceran community}

The variation of the physico-chemical parameters and phytoplankton is presented in Figure 2. Water temperature, $\mathrm{pH}$, dissolved oxygen and conductivity were relatively constant during the study period. The mean water temperature was $17.8{ }^{\circ} \mathrm{C}$, ranging from 15.2 to $21.0{ }^{\circ} \mathrm{C}$. $\mathrm{pH}$ values were alkaline and the dissolved oxygen levels were relatively high. Chlorophyll $a$ content varied in time between $c a .15-53 \mu \mathrm{g} . \mathrm{L}^{-1}$, with an increasing trend at the end of April-start of May. Phytoplankton showed a high density, ranging from $1.6 \times 10^{6}$ cell. $\mathrm{mL}^{-1}$ at the beginning of the study to $10.8 \times 10^{6}$ cell. $\mathrm{mL}^{-1}$ at the end. However, its diversity was essentially limited to Chlorophyta, Bacillariophyceae and cyanobacteria. The Chlorophyta community was constituted mainly of cenobial forms of large size (e.g., Coelastrum reticulatum, Pediastrum simplex, Pediastrum duplex and Scenedesmus sp.). All the Bacillariophyceae were filamentous, except Stephanodiscus sp. and Cyclotella sp., and the major species of cyanobacteria were the filamentous $A$. flos-aquae and the colonial $M$. aeruginosa. A shift in the phytoplankton dominance 

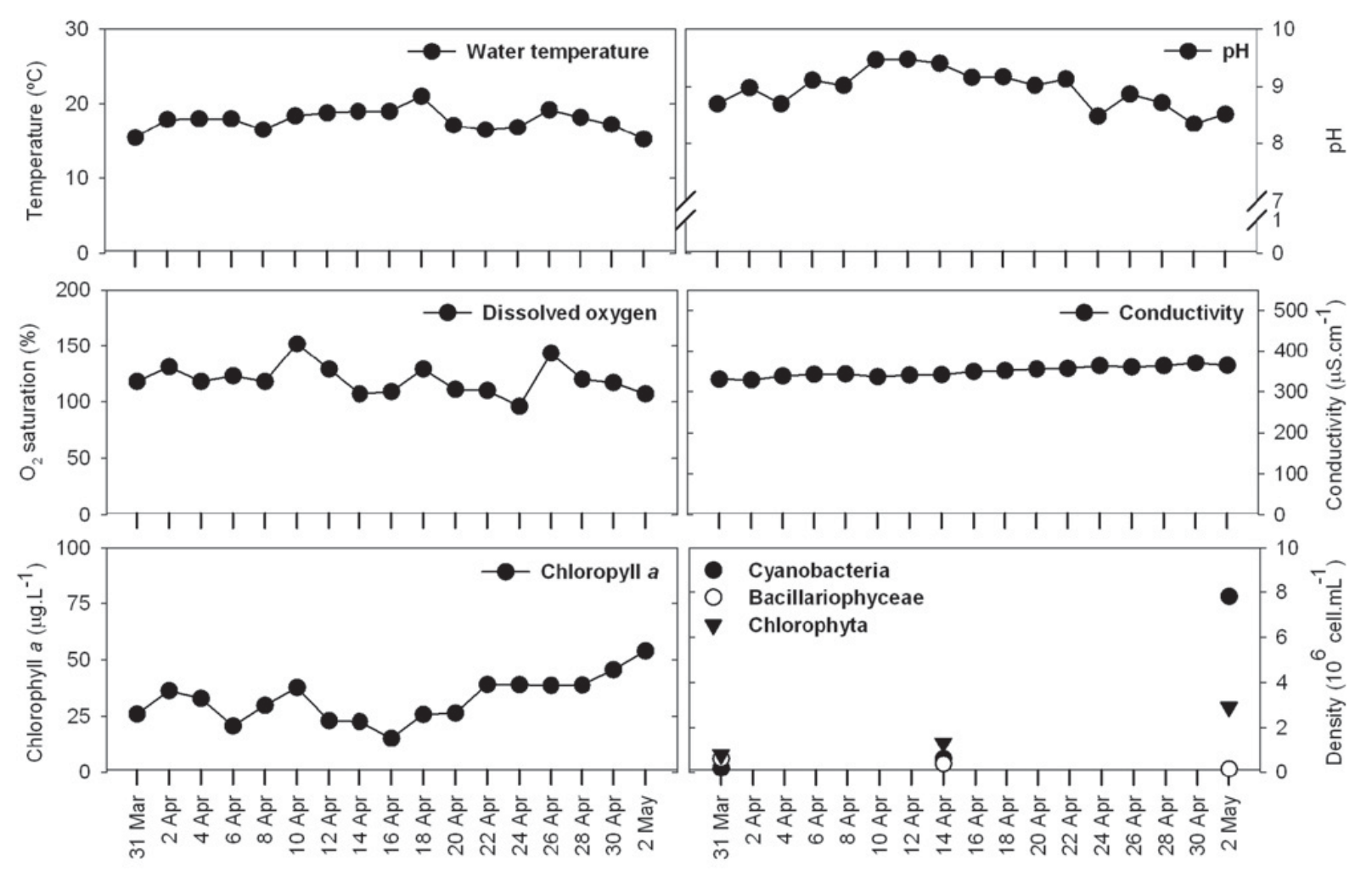

2001

2001

Fig. 2. Environmental variables recorded in Lake Vela during the study period.

was recorded during the study period. Chlorophyta, the dominant group at the beginning, was replaced by cyanobacteria, whose increase was due to the occurrence of the A. flos-aquae bloom. Nevertheless, an increase in Chlorophyta was also observed. In contrast, Bacillariophyceae showed a slight decrease during the study period.

The major cladoceran taxa recorded were Daphnia longispina, Bosmina longirostris, Ceriodaphnia pulchella and Chydorus sp. (Fig. 3). In general, D. longispina and B. longirostris were the dominant cladocerans. The peak recorded for $D$. longispina was coincident with the minimum density of B. longirostris. After April 20, the density of $D$. longispina decreased drastically, associated with an increase of B. longirostris and Chydorus sp. C. pulchella showed a low density when compared with previous studies, in which C. pulchella was one of the most prevalent species (Barros, 1994). Moreover, its density was rather constant during the study period.

\section{C. pulchella population analysis}

The variations in the population parameters of C. pulchella are illustrated in Figure 4. The instantaneous birth rate $(b)$ showed several fluctuations, with a slight declining trend over time. The death rate $(d)$ and the instantaneous rate of population increase $(r)$ varied during the study period but did not show any clear trend.
The mean fecundity and the percentage of ovigerous females also showed a decreasing tendency throughout the study. The mean fecundity varied between 3.8 eggs.adult ${ }^{-1}$ in April 4 to 1.4 eggs.adult ${ }^{-1}$ in April 30. The percentage of ovigerous females showed high variations, ranging from a maximum of $55 \%$ on April 10 to a minimum of about $8 \%$ on April 20. The percentage of males was very low, with a maximum of $3.9 \%$ recorded at the beginning of the study. During the whole study period the presence of individuals with ephippia or cyclomorphosis was not observed. The size at first reproduction, in general, decreased from $0.55 \mathrm{~mm}$ to $0.50 \mathrm{~mm}$ after April 14. The mean size of the ovigerous females as well as the maximum size attained by adults showed an analogous trend to some of the above-mentioned parameters (i.e. with a slight decreasing trend during the study period).

The results of the regression analyses are shown in Table 1. Statistically significant linear relationships were detected between fecundity and percentage of ovigerous females, mean size of ovigerous females and maximum size of adult population. The length/weight regression also showed a statistically significant linear relationship with a high coefficient of determination $\left(r^{2}=0.936\right)$. Water temperature and chlorophyll $a$ did not show any significant relationship with the demographic and morphologic parameters analysed.

The modal analysis performed to C. pulchella population allowed the identification of approximately $21 \mathrm{co-}$ horts throughout the study period (Fig. 5). This analysis 


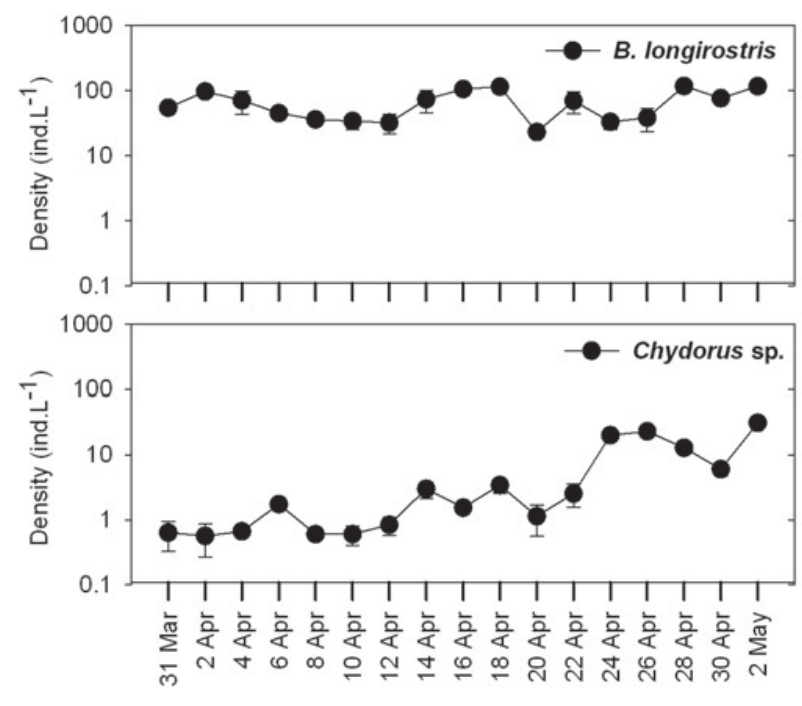

2001

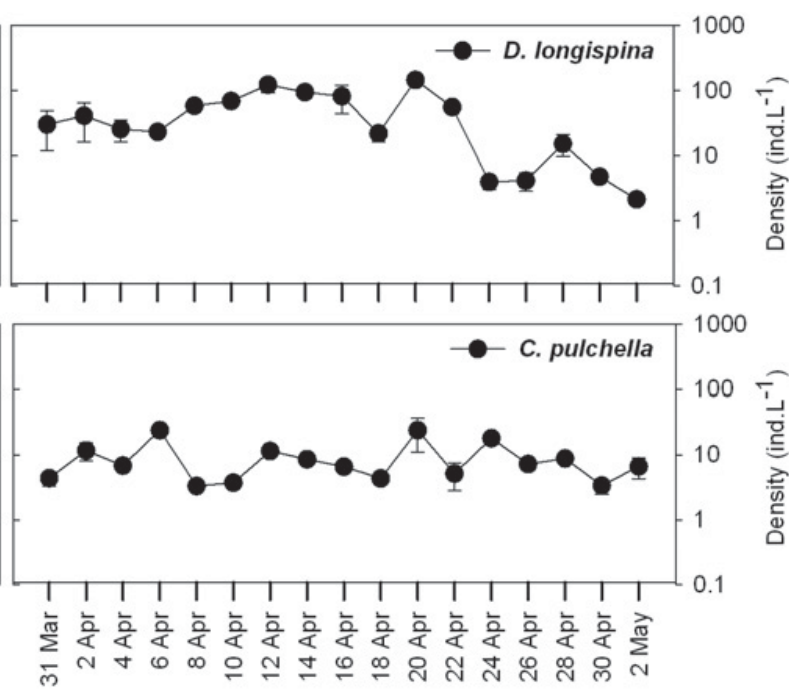

2001

Fig. 3. Densities of the main cladoceran taxa observed during the study period in Lake Vela. A log scale was used to display densities in order to facilitate the comparison of different orders of magnitude of the several taxa.

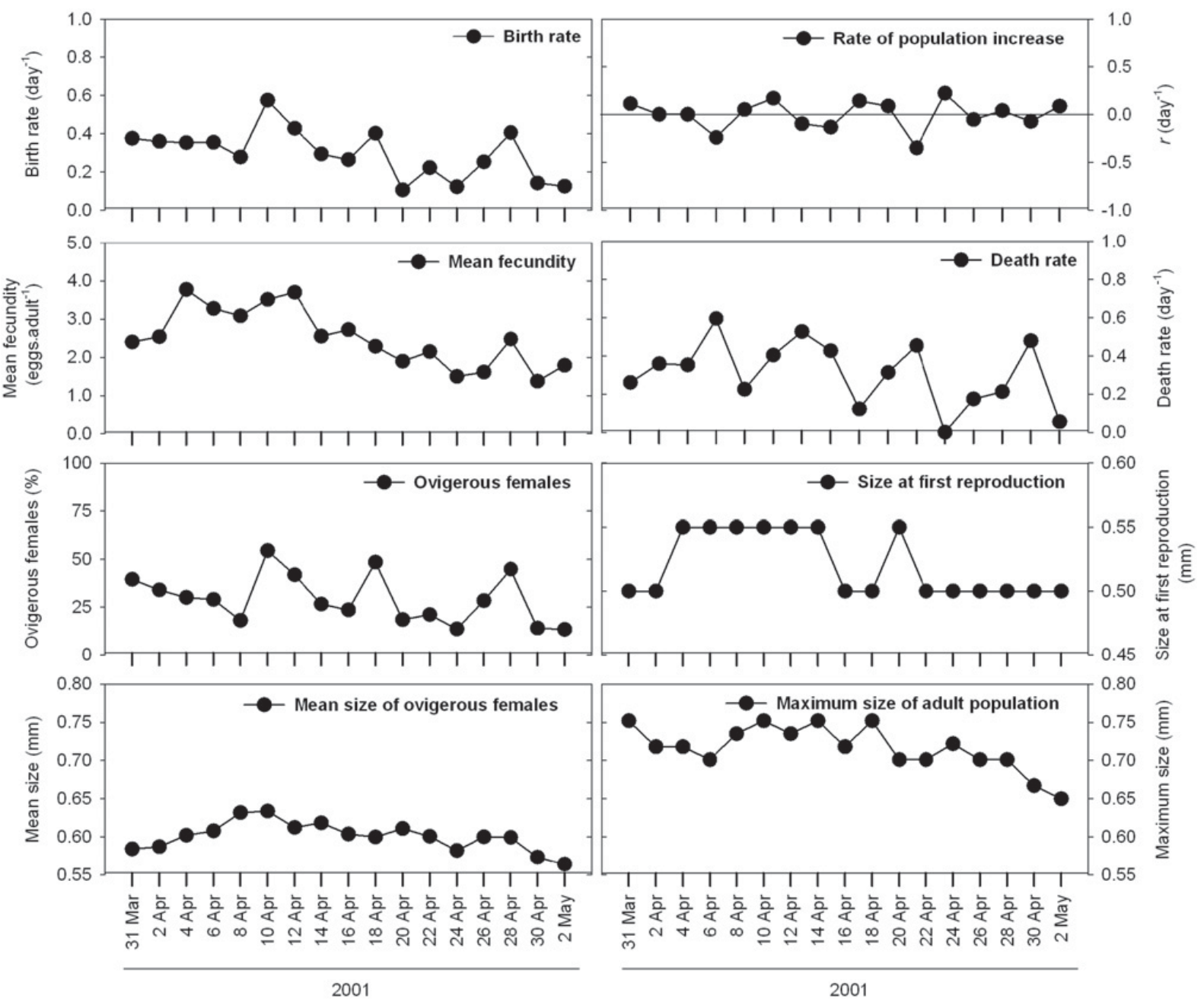

Fig. 4. Population parameters of Ceriodaphnia pulchella recorded during the study period. 
Table 1. Simple linear relationships between several variables. The regression lines and respective coefficients of determination $\left(r^{2}\right)$ are shown for each regression. In this table are only presented the statistically significant linear relationships found $(p \leq 0.05)$.

\begin{tabular}{|c|c|c|c|}
\hline Variables & Slope & $r^{2}$ & $p$ \\
\hline Fecundity $\times$ percentage of ovigerous females & 0.032 & 0.284 & 0.027 \\
\hline Fecundity $\times$ mean size of ovigerous females & 26.155 & 0.417 & 0.005 \\
\hline Fecundity $\times$ maximum size of adult population & 12.748 & 0.245 & 0.044 \\
\hline Weight $(\ln ) \times$ Body length $(\ln )$ & 1.842 & 0.936 & $<0.001$ \\
\hline
\end{tabular}

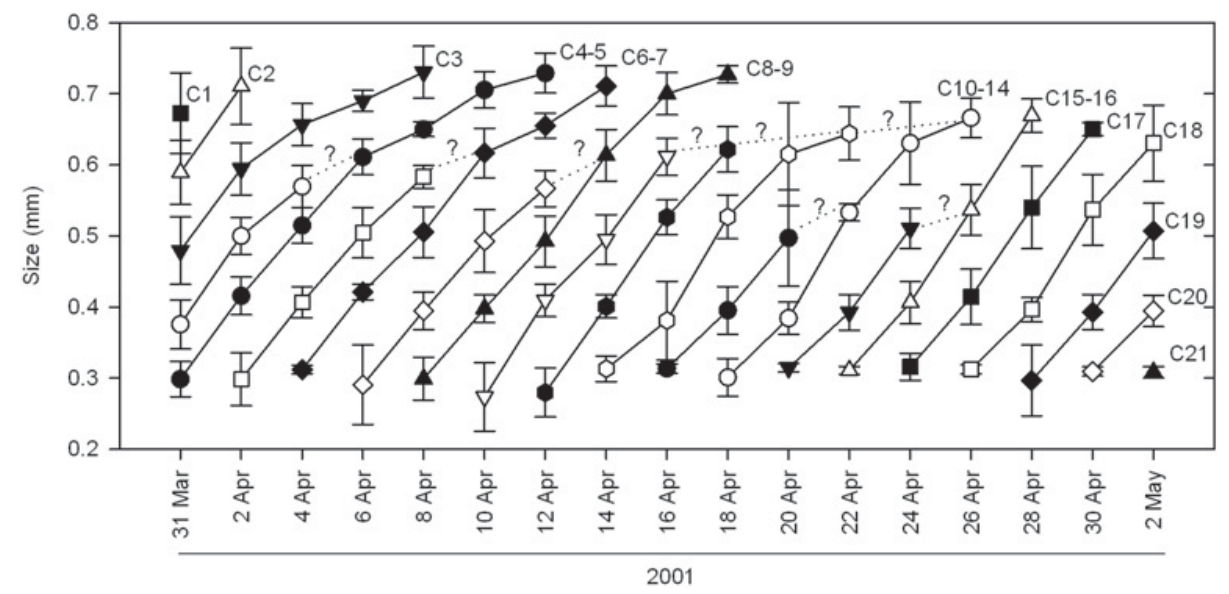

Fig. 5. Evolution of Ceriodaphnia pulchella cohorts $(\mathrm{C} 1-\mathrm{C} 21)$ during the study period. Dashed lines represent possible evolutions. Error bars indicate the standard error.

showed also that $C$. pulchella was characterized by a shortlife cycle and a short generation time.

\section{Discussion}

In general, the literature on environmental fluctuations of phytoplankton and zooplankton is focused on seasonal and annual patterns and therefore the short-term variations are dismissed. The present study provides evidence of the short-term changes in the population dynamics that occurred as a consequence of the cyanobacteria dominance in Lake Vela.

The high chlorophyll $a$ content and the high cyanobacteria density recorded in Lake Vela are representative characteristics of eutrophic lakes (Jeppesen et al., 1999). The variation observed for chlorophyll $a$, particularly the increase recorded after April 20, was very likely associated with the occurrence of the A. flos-aquae bloom that was responsible for the cyanobacteria increase. The warm temperatures in spring, typical of Mediterranean regions, possibly allied with cladoceran grazing pressure on small edible phytoplankton, enable the faster growth of cyanobacteria in Lake Vela, and consequently promote its dominance and the bloom development (Abrantes et al., 2006).

Cyanobacteria are widely considered low quality food for zooplankton, particularly for Daphnia sp., due to their filamentous or colonial structure, nutritional inadequacy and toxin production (e.g., Arnold, 1971; Haney, 1987; Lampert, 1987; Reinikainen et al., 1994; Gulati and
DeMott, 1996; Repka, 1996, 1997; DeMott, 1999; DeMott et al., 2001; Rohrlack et al., 2001; Ghadouani et al., 2003). In particular, the main cyanobacteria species recorded in Lake Vela during the study period (A. flosaquae), have been reported as toxic species, able to produce toxins (e.g. PSP) (Vasconcelos et al., 1993; de Figueiredo et al., 2004a, 2004b). Moreover, beside the toxins' effects on zooplanktonic species, clogging by large cyanobacterial colonies, have been also suggested as the main mechanism responsible for the zooplankton decline (Ghadouani et al., 2006). On the other hand, the large sizes assumed by the diatoms and cenobial Clorophyta species recorded during the study period exclude them from the small cladocerans diet. In this way, although Lake Vela is very productive, this does not necessarily imply high quantity and quality of phytoplanktonic food for cladocerans.

In general, small-bodied size cladocerans are less affected by cyanobacteria (Berzins and Pejler, 1989; Radwan and Popiolek, 1989; Pinel-Alloul, 1993), and the replacement of large species by small ones is common during periods of cyanobacteria dominance (Lampert, 1982). These findings were also observed in Lake Vela. A drastic reduction in the $D$. longispina abundance was coincident with the increase of cyanobacteria density, and simultaneously an increase in the density of the small cladocerans B. longirostris and Chydorus sp. was observed. Regarding the low variability in $C$. pulchella density throughout the study, even during the cyanobacteria dominance, it seems that this species was also not affected by cyanobacteria, particularly by the filamentous species 
A. flos-aquae. Besides the small size of C. Pulchella that limits the ingestability of large filaments, this fact could be also related to its diversified diet, particularly with the efficient consumption of bacteria when the edible algal items are limited (DeMott, 1989). Moreover, C. pulchella population showed a stronger relationship between weight and size, reinforcing the idea that the low quality of phytoplanktonic food did not play an important role on its fitness (Duncan, 1985).

Temperature is also a major factor that influences the life history traits of cladocerans (Burns, 1969; Goss and Bunting, 1983; Orcutt and Porter, 1984). However the water temperature showed relative constant values throughout the study with no apparent effects on the cladocerans dynamics. Despite this, it is important to consider the contribution of temperature to the massive growth of cyanobacteria (Abrantes et al., 2006), which consequently constrains the cladoceran populations, as already reported.

During the study period, C. pulchella exhibited a decrease in the maximum body size and size at first reproduction, which is concordant with size-selective predation from fish hypothesis (Machacek, 1991; Stibor, 1992; Gliwicz, 1994). Based on this hypothesis, when the density of the largest cladoceran in Lake Vela (i.e. D. longispina) decreased considerably, probably as a consequence of the increase of cyanobacteria, $C$. pulchella becomes the species mainly predated by fish due to its larger size compared with B. longirostris and Chydorus sp. Although fish densities were not measured, parallel works confirmed the presence of several planktivorous fish in Lake Vela (e.g., Lepomis gibbosus and Gambusia holbrooki and age-0 Micropterus salmoides). Moreover, Castro et al. (2007) highlight the important role of planktivorous fish on zooplankton in Lake Vela. On the other hand, predatory pressure from pelagic invertebrates is negligible, as potential predators, such as Chaoborus, are rarely found in Lake Vela. The decrease in the fecundity of $C$. pulchella observed during the study, which was associated with the mean size of ovigerous females and maximum size of the population, can be explained by the selective removal of individuals with larger clutches by planktivorous fish.

Regarding the life-history traits of C. pulchella and the output of the modal analysis, a fast turnover of individuals in a short-term equilibrium (with similar birth and death rates) was noticeable. This feature could also constitute an advantage for $C$. pulchella under short-term variations in environmental conditions, allowing a fast adaptive response of the population.

There is a wealth of literature documenting the plasticity of morphological and life-history traits of cladocerans as a response or adaptation to environmental variations. However, the changes shown by organisms, in general, do not occur as a response to a single factor, but to a complexity of interactions generated by a wide range of factors (Machacek, 2001). On these grounds, even when we know the impacts generated by an isolated factor, we are not sure of its influence among other factors interacting under various field scenarios. In this way, although the results showed a clear variation in the cladocerans structure and in the morphologic and life-history traits of C. pulchella during the sort-term period of study, we can only hypothesize about the relative importance of a certain factor. Nevertheless, this study underpinned the importance of considering the short-term variations of the environmental factors in limnological studies.

Acknowledgements. This work was partially funded by Universidade de Aveiro, in the form of an M.Sc. grant to Nelson Abrantes. We are grateful to Doctor Catarina Marques for helpful suggestions.

\section{References}

Abrantes N. and Goncalves F., 2003. The dynamics of Ceriodaphnia pulchella (Cladocera) in laboratory. Acta Oecol., 24, S245-S249.

Abrantes N., Antunes S.C., Pereira M.J. and Goncalves F., 2006. Seasonal succession of cladocerans and phytoplankton and their interactions in a shallow eutrophic lake (Lake Vela, Portugal). Acta Oecol., 29, 54-64.

A.P.H.A., 1995. Standard Methods for the Examination of Water and Wastewater, 19th edn., American Public Health Association, Washington.

Amoros C., 1984a. Introduction pratique à la systématique des organismes des eaux continentales françaises. Crustacés cladocères. Bull. Mens. Soc. Linn. Lyon, 3, 72-107.

Amoros C., 1984b. Introduction pratique à la systématique des organismes des eaux continentales françaises. Crustacés cladocères (suite). Bull. Mens. Soc. Linn. Lyon, 4, 120-144.

Arnold D.E., 1971. Ingestion, assimilation, survival, and reproduction by Daphnia pulex Fed 7 species of blue-greenalgae. Limnol. Oceanogr., 16, 906-920.

Balseiro E.G., Modenutti B.E. and Queimalinos C.P., 1992. The coexistence of bosmina and ceriodaphnia in a South Andes lake - An analysis of demographic responses. Freshwat. Biol., 28, 93-101.

Barros P., 1994. Implicações ecotoxicológicas de cianobactérias em cladóceros, University of Coimbra, Faculty of Sciences and Technology, Coimbra.

Becker C. and Boersma M., 2003. Resource quality effects on life histories of Daphnia. Limnol. Oceanogr., 48, 700-706.

Berzins B. and Pejler B., 1989. Rotifer occurrence and trophic degree. Hydrobiologia, 182, 171-180.

Bird D.F. and Prairie Y.T., 1985. Practical guidelines for the use of zooplankton length-weight regression equations. J. Plankton Res., 7, 955-960.

Boersma M., Spaak P. and De Meester L., 1998. Predatormediated plasticity in morphology, life history, and behavior of Daphnia: The uncoupling of responses. Amer. Nat., 152, 237-248.

Burns C.W., 1969. Relation between filtering rate, temperature, and body size in 4 species of Daphnia. Limnol. Oceanogr., 14, 693-700.

Castro B.B. and Goncalves F., 2007. Seasonal dynamics of the crustacean zooplankton of a shallow eutrophic lake from the Mediterranean region. Fund. Appl. Limnol., 169, 189-202. 
Castro B.B., Marques S.M. and Goncalves F., 2007. Habitat selection and diel distribution of the crustacean zooplankton from a shallow Mediterranean lake during the turbid and clear water phases. Freshwat. Biol., 52, 421-433.

Christoffersen K., Riemann B., Klysner A. and Sondergaard M., 1993. Potential role of fish predation and naturalpopulations of zooplankton in structuring a plankton community in eutrophic lake water. Limnol. Oceanogr., 38, 561-573.

de Figueiredo D.R., Antunes S.C., Pereira M.J. and Goncalves F.G., 2004a. Chronic effects of Aphanizomenon flos-aquae on the survival and reproduction of daphnids. Fresenius Environ. Bull., 13, 665-670.

de Figueiredo D.R., Azeiteiro U.M., Esteves S.M., Goncalves F.J.M. and Pereira M.J., 2004b. Microcystin-producing blooms Coimbra a serious global public health issue. Ecotox. Environ. Safety, 59, 151-163.

de Figueiredo D.R., Reboleira A., Antunes S.C., Abrantes N., Azeiteiro U., Goncalves F. and Pereira M.J., 2006. The effect of environmental parameters and cyanobacterial blooms on phytoplankton dynamics of a Portuguese temperate lake. Hydrobiologia, 568, 145-157.

DeMott W.R., 1989. The role of competition in zooplankton succession. In: Sommer U. (ed.), Plankton Ecology: Succession in Plankton Communities, Springer-Verlag, Berlin, 195-252.

DeMott W.R., 1999. Foraging strategies and growth inhibition in five daphnids feeding on mixtures of a toxic cyanobacterium and a green alga. Freshwat. Biol., 42, 263-274.

DeMott W.R., Gulati R.D. and Van Donk E., 2001. Daphnia food limitation in three hypereutrophic Dutch lakes: Evidence for exclusion of large-bodied species by interfering filaments of cyanobacteria. Limnol. Oceanogr., 46, 20542060.

Duncan A., 1985. Body carbon in daphnids as an indicator of the food concentration available in the field. Adv. Limnol., 21, $81-90$.

Geitler L., 1932. Cyanophyceae von Europa. In: Kolkwitz R. (ed.), Dr. L. Rabenhorst's Kryptogamen-Flora von Deutschland, Österreich und der Schweiz, Akademische Verlagsgesellschaft, Leipzig, 1-1196.

Ghadouani A., Pinel-Alloul B. and Prepas E.E., 2003. Effects of experimentally induced cyanobacterial blooms on crustacean zooplankton communities. Freshwat. Biol., 48, 363-381.

Ghadouani A., Pinel-Alloul B. and Prepas E.E., 2006. Could increased cyanobacterial biomass following forest harvesting cause a reduction in zooplankton body size structure? Can. J. Fish. Aquat. Sci., 63, 2308-2317.

Gliwicz Z.M., 1994. Relative significance of direct and indirect effects of predation by planktivorous fish on zooplankton. Hydrobiologia, 272, 201-210.

Goss L.B. and Bunting D.L., 1983. Daphnia development and reproduction - Responses to temperature. J. Thermal Biol., 8, 375-380.

Greenwood T.L., Green J.D., Hicks B.J. and Chapman M.A., 1999. Seasonal abundance of small cladocerans in Lake Mangakaware, Waikato, New Zealand. New Zeal. J. Mar. Fresh., 33, 399-415.

Gulati R.D. and DeMott W.R., 1996. The role of food quality for zooplankton: remarks on the state-of-the-art, perspectives and priorities. In: 1st International-Plankton-Ecology-
Group Workshop on the Role of Food Quality for Zooplankton, Nieuwersluis, 38, 753-768.

Haney J.F., 1987. Field studies on zooplankton-cyanobacteria interactions. New Zeal. J. Mar. Fresh., 21, 467-475.

Haney J.F. and Hall D.J., 1973. Sugar-coated DaphniaPreservation technique for Cladocera. Limnol. Oceanogr., $18,331-333$.

Hessen D.O., Faafeng B.A. and Brettum P., 2003. Autotroph: herbivore biomass ratios; carbon deficits judged from plankton data. Hydrobiologia, 491, 167-175.

Hulsmann S., 2001. Reproductive potential of Daphnia galeata in relation to food conditions: implications of a changing size-structure of the population. Hydrobiologia, 442, 241252.

Hulsmann S., Vijverberg J., Boersma M. and Mooij W.M., 2004. Effects of infochemicals released by gape-limited fish on life history traits of Daphnia: a maladaptive response? J. Plankton Res., 26, 535-543.

Jeppesen E., Jensen J.P., Sondergaard M. and Lauridsen T., 1999. Trophic dynamics in turbid and clearwater lakes with special emphasis on the role of zooplankton for water clarity. Hydrobiologia, 408, 217-231.

Komárek J. and Anagnostidis K., 1999. Cyanoprokaryota 1, Teil: Chroococcales. Süßwasserflora von Mitteleuropa, Gustav Fischer Verlag, Jena.

Komárek J. and Fott B., 1983. Das Phytoplankton des Süßwassers, Systematik und Biologie. 7. Teil, 1. Hälfte, Chlorophyceae (Grünalgen). Ordnung: Chlorococcales, Schweizerbart'sche Verlagsbuchhandlung, Stuttgart.

Krammer K. and Lange-Bertalot H., 1986-1991. Bacillariophyceae. 1-4. Süßwasserflora von Mitteleuropa, Gustav Fischer Verlag, Stuttgart.

Lampert W., 1978. Field-study on dependence of fecundity of Daphnia spec. on food concentration. Oecologia, 36, 363369.

Lampert W., 1982. Further-studies on the inhibitory effect of the toxic blue-green Microcystis aeruginosa on the filtering rate of zooplankton. Arch. Hydrobiol., 95, 207-220.

Lampert W., 1987. Laboratory studies on zooplanktonCyanobacteria interactions. New Zeal. J. Mar. Fresh., 21, 483-490.

Lampert W., 1988. The relative importance of food limitation and predation in the seasonal cycle of two Daphnia species. Internationale Vereinigung für Theoretische und Angewandte Limnologie Verhandlungen, 23, 713-718.

Lampert W., 1993. Phenotypic plasticity of the size at 1st reproduction in Daphnia - The importance of maternal size. Ecology, 74, 1455-1466.

Lampert W., 1994. Phenotypic plasticity of the filter screens in Daphnia - Adaptation to a low-food environment. Limnol. Oceanogr., 39, 997-1006.

Lampert W. and Brendelberger H., 1996. Strategies of phenotypic low-food adaptation in Daphnia: Filter screens, mesh sizes, and appendage beat rates. Limnol. Oceanogr., 41, 216223.

Lund J.W.G., Kipling C. and Le Cren E.D., 1958. The inverted microscope method of estimating algal numbers and the statistical basis of estimations by couting. Hydrobiologia, 11, 143-170.

Machacek J., 1991. Indirect effect of planktivorous fish on the growth and reproduction of Daphnia galeata. Hydrobiologia, 225, 193-197. 
Machacek J., 2001. Daphnia galeata life history response to heterogeneous food conditions and dissolved chemicals in the Rimov Reservoir. Hydrobiologia, 442, 215-222.

Müller-Navarra D. and Lampert W., 1996. Seasonal patterns of food limitation in Daphnia galeata: Separating food quantity and food quality effects. J. Plankton Res., 18, 1137-1157.

Nogueira A.J.A., 1992. Anamod - Extracção dos componentes modais de distribuições de frequência de variáveis biométricas, University of Coimbra, Faculty of Sciences and Technology, Coimbra.

Orcutt J.D. and Porter K.G., 1984. The synergistic effects of temperature and food concentration on life-history parameters of Daphnia. Oecologia, 63, 300-306.

Paloheimo J.E., 1974. Calculation of instantaneous birth-rate. Limnol. Oceanogr., 19, 692-694.

Pinel-Alloul B., 1993. Zooplankton community structure in hardwater hypertrophic lakes of Alberta. Wat. Sci. Technol., 27, 353-361.

Polishchuk L.V. and Vijverberg J., 2005. Contribution analysis of body mass dynamics in Daphnia. Oecologia, 144, 268-277.

Radwan S. and Popiolek B., 1989. Percentage of Rotifers in spring zooplankton in lakes of different trophy. Hydrobiologia, 186, 235-238.

Reede T., 1995. Life-history shifts in response to different levels of fish Kairomones in Daphnia. J. Plankton Res., 17, 16611667.

Reinikainen M., Ketola M. and Walls M., 1994. Effects of the concentrations of toxic Microcystis aeruginosa and an alternative food on the survival of Daphnia pulex. Limnol. Oceanogr., 39, 424-432.

Repka S., 1996. Inter- and intraspecific differences in Daphnia life histories in response to two food sources: The green alga Scenedesmus and the filamentous cyanobacterium Oscillatoria. J. Plankton Res., 18, 1213-1223.

Repka S., 1997. Effects of food type on the life history of Daphnia clones from lakes differing in trophic state. I. Daphnia galeata feeding on Scenedesmus and Oscillatoria. Freshwat. Biol., 38, 675-683.
Rohrlack T., Dittmann E., Borner T. and Christoffersen K., 2001. Effects of cell-bound microcystins on survival and feeding of Daphnia spp. Appl. Environ. Microbiol., 67, 35233529.

Scourfield D.J. and Harding J.P., 1966. A key to the British freshwater Cladocera, 3rd edn., Freshwater Biological Association, Sciencific Publication 5, Ambleside.

Smolders R., Baillieul M. and Blust R., 2005. Relationship between the energy status of Daphnia magna and its sensitivity to environmental stress. Aquat. Toxicol., 73, 155-170.

Sommer U., Gliwicz Z.M., Lampert W. and Duncan A., 1986. The PEG-model of seasonal succession of planktonic events in fresh waters. Arch. Hydrobiol., 106, 433-471.

Stibor H., 1992. Predator induced life-history shifts in a freshwater Cladoceran. Oecologia, 92, 162-165.

Tollrian R. and Dodson S.I., 1999. Inducible defences in cladocera: constrains, costs, and multipredator environments. In: Tollrian R. and Harvell C.D. (eds.), The Ecology and Evolution of Inducible Defenses, Princeton University Press, 177-202.

Vanni M.J. and Lampert W., 1992. Food quality effects on lifehistory traits and fitness in the generalist herbivore Daphnia. Oecologia, 92, 48-57.

Vasconcelos V.M., Evans W.R., Carmichael W.W. and Namikoshi M., 1993. Isolation of microcystin-LR from a Microcystis (Cyanobacteria) waterbloom collected in the drinking-water reservoir for Porto, Portugal. J. Environ. Sci. Heal. A, 28, 2081-2094.

Vijverberg J. and Boersma M., 1997. Long-term dynamics of small-bodied and large-bodied cladocerans during the eutrophication of a shallow reservoir, with special attention for Chydorus sphaericus. Hydrobiologia, 360, 233242.

Viroux L., 2002. Seasonal and longitudinal aspects of microcrustacean (Cladocera, Copepoda) dynamics in a lowland river. J. Plankton Res., 24, 281-292.

Wetzel R.G., 1993. Limnologia, 2nd edn., Fundação Calouste Gulbenkian, Lisboa. 